brazilianpoliticalsciencereview

BOOK REVIEW

\title{
Electoral Systems and Judicial Review in Developing
}

\section{Countries*}

\author{
Ernani Carvalho \\ Universidade Federal de Pernambuco, Brazil \\ Leon Victor de Queiroz Barbosa \\ Universidade Federal de Campina Grande, Brazil
}

(Yadav, Vineeta and Mukherjee, Bumba. Democracy, Electoral Systems, and Judicial Empowerment in Developing Countries. Michigan Press, 2014)

The interest regarding the effects a strong Judiciary may have on political systems has a long history. Tocqueville in his seminal work Democracy in America had already warned us of such phenomenon centuries ago ${ }^{1}$. Very recently, political science as a discipline has dealt with the global phenomenon of the expansion of Judiciary Power. This process presents itself through various levels of social relations up until the political level. In the specific field of politics, we may see the growing inclusion of the Judiciary as an important, and often decisive, actor in decision-making processes ${ }^{2}$.

The purpose of this book is to study the determinants in the constitutional empowerment (or lack thereof) of the judiciary in young democracies in developing countries, examining the conditions through which the judiciary was granted the important legal mechanism of judicial review. The book also attempts

(*) http://dx.doi.org/10.1590/1981-38212015000300024

${ }^{1}$ Robert Dahl also sought to understand this phenomenon, a strictly US issue at the time (1957).

2 A vast literature addresses judicial empowerment in Western democracies: Ferejohn (2002); Hirschl (2001, 2004); Koopmans (2003) and Tate and Valinder (1995), among others. 
to analyze policies maintaining a de facto independence from the courts in newly established democracies in developing countries. The authors seek answers by analyzing the interaction between government, opposition, and the judiciary across different contexts of domestic institutions and political conditions. Subsequently, the authors empirically test their answers with statistical tests and, in the end, select sets and compare them in order to illustrate the underlying causal dynamics of adopting institutional judicial review (de jure) and judicial independence in practice (de facto) within the democracies of developing countries ${ }^{3}$.

In the first chapter, the authors state the research questions. The book's initial question is: why did governments in some young democracies explicitly adopt judicial review in the early years of democratic transition while other countries did not? According to the authors, researchers have identified important factors for this distinction, such as political fragmentation, electoral uncertainty, and Human Rights protection as crucial determinants for adopting judicial review. However, they did not explain all the judicial review variations (de jure) observed in young developing democracies. However, these studies cannot focus solely on the institutional design (de jure) of judicial review. One must analyze the independence of the judiciary in practice (de facto). Some researchers associate de facto independence to the separation of powers and the higher levels of political competition, as they create a more uncertain environment for electoral results, leading political elites to develop strategies to deal with the challenges of domestic politics established by this environment. Other studies indicate that, for example, elites create strategies to safeguard themselves against future retaliations from the opposition. In the short term, elites react to uncertainty by creating a genuinely independent judiciary. In contrast, the long-term associated with low competitive politics establishes incentives for the elite to increase their own power by restricting judicial independence.

These arguments do not stand against the authors' elaborate study. By using a risk rate (likelihood of government collapse) as a proxy for strategies over time (short and long term), the results showed that a high risk-rate (equivalent to

\footnotetext{
3 This multi-method strategy was singled out as a solution for the field of legal studies, given the complexity of its comparative approach, as indicated by Baum (1997).
} 
short-term) of governments in power are associated with an increase of de facto judicial independence of $56 \%$ within the sample of developing countries. However, the remaining $44 \%$ contradict theoretical expectations and show that an increase in the risk rate is associated with a decrease in judicial independence. This conundrum leads to the book's second question: why do countries invest at different levels in judicial independence?

The second chapter provides the theoretical framework seeking answer two questions: 1) During the early years of transitional governments, why did some democracies (but not others) deny or constitutionally restrict full judicial review? 2) Why does high political competition, by reducing the expected time in power, provide incentives to the government in some democracies to protect and enhance judicial independence, but induces other governments to curtail the judiciary's autonomy? The literature shows that judicial independence (de jure or de facto) is the result of strategic interactions between key rational actors insofar that they confront and seek to resolve several political challenges to stay in power.

The authors attempt to connect the institutional characteristics of a country to its choice to institutionalize judicial review and the level of de facto judicial independence.

Changes in the institutional design of judicial review and in the de facto independence of the courts in democracies in developing countries lead to the question: why and when are governments of the world's developing democracies less likely to adopt full judicial review in the early years of transition? The first hypothesis is that governments controlling a sufficient number of legislative seats are less likely to adopt judicial review if public confidence in the judiciary increases in the periods immediately after the transition. The second hypothesis states that in the context of high risk-rates in power, incumbents in personalist electoral systems (centered on the candidate) are more likely to increase de facto judicial independence.

In the third chapter, the authors statistically test the hypotheses from the previous chapter. The database contains a sample of 159 developing countries between 1985 and 2004, using the time-series cross-section technique (TSCs) similar to panel data. The dependent variable for testing the first hypothesis measures the extent to which constitutional rules grant courts with full and 
explicit judicial review, using an ordinal scale ranging from -01 to 02 , where the lower value means that the constitution assigns judicial review to another power, such as the executive or the legislative, and the highest value means the judiciary exercises full judicial review. The model uses two independent variables: 1) the concentration of legislative seats controlled by the government in new democracies in the early post-transition years; 2) a continuous measurement of the citizens' trust in the judiciary. A series of control variables also comprise the ordinal Probit model with random effects. The results corroborate the first hypothesis, i.e., governments in new democracies in the developing world controlling a high concentration of parliamentary seats after the transition election are less likely to adopt judicial review if public confidence in the Judiciary is sufficiently high. The data also reveals that incumbents in new democracies are more likely to establish courts with the constitutional authority for judicial review if the concentration of parliamentary seats by the first party in power in the posttransition and public confidence in the Judiciary are both low. These results convey two substantive implications: 1) numerous studies have suggested that the transition to democracy in developing countries increases the prospects of a constitutional design that contemplates an independent and politically autonomous Judiciary. In fact, as shown, the likelihood that elites empower the judiciary of new democracies in developing countries with constitutional judicial review depends on two factors: a) the concentration and control of legislative seats at the beginning of the post-transition period; b) the extent of the public trust in the Judiciary; 2) studies on democratization and empowerment of judicial policies often focus on the impact of political institutions on the de jure judicial independence. One must be cautious to realize when and how political institutions may increase the courts' judicial autonomy. The book results show that when governments control a substantial amount of seats in the Legislative and public trust in the legal system increases, the lower the probability of adopting judicial review. This serves as a restriction of the Judiciary's political autonomy.

Chapter four provides a case study of Brazil and Indonesia to illustrate the causal arguments leading to the first hypothesis. The Indonesian case reveals that the Executive in the first post-transition period did not have enough incentives to empower the courts with constitutional guarantees to exercise full judicial review 
when the concentration of parliamentary seats managed by the government was sufficiently high. In contrast, the Brazilian case shows that incumbents are more likely to empower the judiciary with constitutional guarantees to exercise full and explicit judicial review when the concentration of parliamentary seats is low. This means that government control over the Legislature is a necessary condition, albeit not sufficient to affect the likelihood of the Executive constitutionally empowering the courts to review laws and public policies approved by the legislature. Both cases are useful for analyzing the likelihood with which incumbents in new democracies endow the judiciary with judicial review. Two points must be considered when addressing the Brazilian case: 1) the control of a low concentration of parliamentary seats means further uncertainty. Ginsburg (2003) had already stated that two key elements might increase judicial empowerment: political fragmentation and an environment of political uncertainties, causing incumbents to adopt a political survival strategy to endow the Judiciary with judicial review powers. This is what Ginsburg (2003) calls insurance. 2) When the authors refer to a low concentration of parliamentary seats, they do not mention the degree of ideological homogeneity or heterogeneity in such concentration. This has direct connections to the environment of political uncertainty. The FHC and Lula coalitions held more than $60 \%$ of parliamentary seats, but while the former had higher degree of homogeneity, the latter was very heterogeneous. Nevertheless, the post-transition moments in which the Brazilian judiciary emerged stronger were in 1988 and 2004. Barbosa (2015) created a Judicial Empowerment indicator for Brazil, showing that the prime inclinations occurred between 1985-1988 and 2002-2004, where the government held respectively $41.75 \%$ and $62.38 \%$ of parliamentary seats.

This finding corroborates the authors' argument for the 1985-1988 period. What could explain a strong judicial empowerment such a long time after the transition? Uncertainty, perhaps? While concentration was quite homogeneous in the $1985-88$ period (only the president's party had over $40 \%$ of the Chamber of Deputies, requiring only one other party to reach quorum for Constitutional amendment), in the 2002-2004 period, even with a concentration superior to $60 \%$ of the legislature, eight parties were necessary to set forth constitutional 
amendments, since the president's party encompassed no more than $17.7 \%$ of Deputies.

The fifth chapter deals with de facto judicial independence and tests the second hypothesis. The authors use a sample, also in TSCs format, with 103 developing countries considered democracies at any time between 1985 and 2004. The dependent variable in the model is de facto judicial independence. This variable is ordinal and ranges from zero to two, where zero means no judicial independence and two means a generally independent Judiciary or de facto independent. Two independent variables are included in the model: 1) the duration of the government or the equivalent to its risk rate; and 2) the degree of particularity ${ }^{4}$ of the electoral system. The statistical technique is the same as the previous model, ordinal Probit with random effects. The results confirmed the hypothesis, i.e., in a high risk-rate context during the administrative term, the incumbents in personalist electoral systems are probabilistically more prone to increase de facto judicial independence. The results have two main substantive implications: 1) many researchers have recognized that judicial independence cannot be taken for granted as an effective judicial system of checks and balances depends on the appropriate external circumstance. The authors' seek to understand how a key factor (the degree of electoral particularism), which shapes the strategic political environment in which politicians operate, influences decisions in constraining or increasing de facto judicial independence in courts. The results contribute to future researches attempting to explore how electoral systems affect the interaction between incumbents and the courts in developed and developing countries. 2) Several studies suggest, explicitly or implicitly, that the expected amount of time of rulers in power determines whether they will maintain a de facto independence of the courts. The authors also believe that the expected duration of a government, measured by the risk rate, affects political incentives and its decisions to uphold or to curb judicial autonomy. Although the results corroborate the authors' hypothesis, they do not reveal the causal logic steering governments within particularistic electoral systems by increasing de facto judicial independence when the expected duration in power decreases, or the

\footnotetext{
${ }^{4}$ In the sense of personalism, individualism and focused on candidates.
} 
tendency of leaders in party-centered democracies to curtail de facto judicial independence when risk rates are high.

The sixth chapter deals with the judicial de facto independence in personalist electoral systems. The authors emphasize that the challenge of judicial independence in democracies in developing countries do not merely end with attempts toward judicial empowerment. Political leaders face the challenge of maintaining a de facto autonomy of the courts. The authors abandon a large-n approach to examine evidence supporting the second hypothesis: the degree of political individualism of the electoral system in democracies in developing countries plays a crucial role in incentives and in the strategic behavior of politicians when they interact with the Judiciary. When faced with high risk-rates and, therefore, low expectations of remaining in power, governments will tend to restrict de facto judicial independence in countries with party-based electoral systems (low degree of individualism), but will act the opposite when the system is based on candidates (high degree of individualism). The authors sought to strengthen the argument by using two countries with electoral systems highly based on candidates: Brazil and India. Using data from each country through a qualitative approach illustrates that when faced with high-risk rate, theses governments increase the values of judicial independence precisely because of the internal weakness and the low unity level of political parties. As a result, incumbents have strong political incentives to increase the autonomy of the courts when their survival in power becomes seriously threatened. This leads to two implications: 1) in general, governments in democracies with highly individualistic electoral systems (centered on candidates) are more likely to at least maintain de facto judicial independence if the risk rate of staying in power is high. Specifically speaking, de facto judicial autonomy is likely to remain high in Brazil and India in the near future insofar that the government's risk rate in these two countries remains high in the future; 2) it is plausible that the high de facto autonomy in Brazil's and India's courts may lead to further judicial activism. This is crucial since researchers in Brazil have questioned whether judicial activism can increase, decrease, or maintain the status quo in these countries. The authors' belief is that judicial activism in Brazil and India tends to increase. 
The final chapter provides a parallel in the politics of the de facto autonomy of courts in a democracy in a development country displaying low levels of particularism and a high risk-rate. The Indonesian case illustrates the causal arguments that unfold from the second hypotheses, since the Indonesian judiciary is often described as an institution lacking judicial autonomy. The Indonesian case confirms that the degree of centralization within parties (determined by electoral rules) explains why political actors in some democracies in developing countries are more likely to reduce de facto judicial independence when their time in power decreases. The analysis shows that the presence of a closed-list proportional electoral system, with grouped votes and ballots controlled by parties, resulted in strong, centralized parties, which endowed political elites with incentives and capacity to undertake restrictive actions on the independence of the courts.

The book has undertaken a vigorous theoretical and analytical effort, formulating the intertwining of the workings of the political system and its consequences in the strengthening (or otherwise) of judicial institutions. It shows innovation by articulating several methods associated with a strategic perspective ${ }^{5}$ of the functioning of institutions.

Translated by Paulo Scarpa

\section{References}

BAUM, Lawrence (1997), The puzzle of judicial behaviour. Ann Arbor: University of Michigan Press. 215pp.

BARBOSA, Leon Victor de Queiroz (2015), O Silêncio dos incumbentes: fragmentação partidária e empoderamento judicial no Brasil. PhD Dissertation. Departamento de Ciência Política. Universidade Federal de Pernambuco.

DAHL, Robert (1957), Decision-making in a democracy: the Supreme Court as a national policy-maker. Role of the Supreme Court Symposium. № 01.

EPSTEIN, Lee and KNIGHT, Jack (1998), The choices of justices make. Washington: Congressional Quarterly. 186pp.

EPSTEIN, Lee and KNIGHT, Jack (2000), Toward a strategic revolution in judicial politics: A lock back, a look ahead. Political Research Quarterly. Vol. 53, № 03, pp.625-661.

\footnotetext{
${ }^{5}$ For the case of judicial institutions see: Epstein and Knight (1998 and 2000).
} 
FEREJOHN, John (2002), Judicializing politics, politicizing law. Law and Contemporary Problems. Vol. 65, № 03, pp.41-68.

GINSBURG, Tom (2003), Judicial Review in New Democracies: Constitutional Courts in Asian Cases. Edição Kindle. Cambridge: University Press. 310pp.

HIRSCHL, Rans (2001), The political origins of judicial empowerment through constitutionalization: lessons from Israel's Constitutional Revolution. Comparative Politics. Vol. 33, № 03, April. pp. 315-335.

HIRSCHL, Rans (2004), Towards Juristocracy: the origins and consequences of the New Constitutionalism. Harvard: University Press. 144pp.

KOOPMANS, Tim (2003), Courts and political institutions: a comparative view. Cambridge University Press. 299pp.

TATE, C. Neal and VALLINDER Torbjorn (1995), The global expansion of judicial power: the judicialization of politics. New York: New York University Press. 570pp. 